claims to undertake is one that someone really should work on (though more people have worked on it than one would be aware of from Shuster's discussions). Unfortunately, its promise is not followed through.

Christopher Bennett

University of Sheffield

\title{
Carina E. Ray, Crossing the Color Line: Race, Sex, and the Contested Politics of Colonialism in Ghana (Athens: Ohio University Press, 2015). 364 pp. Pa- perback \$32.95.
}

In the past few decades, our understanding of the place of race within Imperialism has greatly expanded. Yet oftentimes the place of individual relationships becomes lost in these larger conversations. Carina E. Ray addresses this deficiency in her intriguing and innovative study of the place of inter-racial relationships within colonial Ghana. Especially important here is that Ray explores all sides of this issue as she examines the place of relationships within Ghana from both an official imperial and a local perspective and then does the same thing for the Ghanaians who found themselves in England.

This well written and researched work continues our quest to understand the role that race played within colonial empires. Ray works to understand this by exploring how these relationships constructed, defined, and challenged empire. By doing so she brings a distinct human element into this history, thereby complicating it when we examine it upon a personal level. She accomplishes this through the effective utilization of individual case studies of specific inter-racial relationships and from this she carefully constructs her analysis. Her study illustrates the complexity of race within the British Empire, the issues that colonial officials had to deal with as they worked to impose their control upon the colonized peoples, how the colonized peoples reacted and adapted to the changes wrought by empire, and, finally, how similar situations in diverse parts of the empire were reacted to differently. Ray not only focuses upon the relationship between the metropole and the colony, but clearly shows how the people of the colony reacted to events within the metropole.

One important theme throughout the work concerns the place of "native marriages" within Ghana. Ghana has a long history of sustained interactions with Europeans, commencing with the 1482 construction of Elmina castle and lasting until the present. Thus, while the relationship between the peoples of the Gold Coast and Britain had radically changed during the period of this study, especially in regards to power and economics, the structures of cross-cultural relations were well-established. As Ray shows, the Akan had a long history of incorporating outsiders into their community and this was especially true during the period of Atlantic Trade. Along the Gold Coast, European traders and company officials, be they Dutch, British, French or Danish, entered into relationships with coastal women; 
an important mid- $18^{\text {th }}$ century relationship involved Richard Brew, a trader at Anomabu, and the daughter of John Curranteer, the Birempon there. The records show that many of these relationships were about trade and power; yet, sporadically, we get insight into the fact that in many cases these were real emotional relationships. Thus, as Ray demonstrates, by the start of the colonial period it was common for local women to enter into relationships with European men. These could be short-term relations within the notion of a country wife or they could be more, such as in her initial example where Felicia Agnes Knight pleaded with Kwame Nkrumah to not destroy her family by removing her husband, Brendan Knight, from his civil service position.

This well-established system of cross-cultural relations was initially accepted within the colonial period in Ghana, but in the early $20^{\text {th }}$ century it came under challenge. An important element of Ray's work involves this challenge to these relationships as inter-racial marriage becomes a moral, imperial, issue. Thus, what was an important element in developing cross-cultural relations within the Gold Coast very quickly became unacceptable. As Ray very carefully and clearly shows, these sexual relations became a threat to the larger racial notions of empire. Within this, Ray demonstrates that the British example was unique in several ways. First, what was interesting in this attack on native wives, most clearly seen in the Crewe Circular of 1909, was the British view of concubinage, or taking a native wife, versus prostitution. It was ok for male British civil servants to satisfy their sexual urges through short-term relations, but when they did this over the large term, by taking a native wife, then it became problematic. Taking a "native wife" signified that the British civil servant was adapting to local Akan customs; it was okay to hire a prostitute but it was not okay to "go native." Coupled with this was the issue of the offspring of these long-term relations. There had long been a multiracial population within the Gold Coast, but for the most part they did not try to remain unique, rather they saw themselves as part of the local culture. This created its own issues within the British civil service in Ghana. Whereas multiracial West Indian servants were viewed as European, multiracial Gold Coast servants were black.

A final important element of Ray's work involves Part Two, where she examines the same issues within the metropole. Both World Wars, coupled with continued economic development, meant that there was a growing, and often transitory and predominately male, Gold Coast population in England. This population usually centred around ports, where Ghanaian males developed relationships with English women. In this situation, like the above, there was a racial fear of the Englishperson, in this case female, "going native," especially when she wished to move to Ghana with her partner, which had to be prevented. Ray does show that added to this was the issue of class as the relationship between sailors or laborers and lower class women were viewed differently from those of, say, the future leaders of Ghana, the educated elite, who were members of WASU and developed their own relationships. An interesting aspect of this, as Ray shows, involves the post-war riots that occurred 
over these relationships and the response that developed in Ghana. Ghanaians questioned how an empire could claim moral superiority by prohibiting interactions between black males and white females but ignored the fact that white males regularly interacted with black females.

Throughout this engaging work, Ray's use of specific cases serves to draw the reader into what was occurring, and the complexity of the situation. The case of Marcus Clark, for instance, demonstrates the disconnect between the tradition of native wives and its sudden outlawing while also demonstrating, as Clark was West Indian, the complexities of race within the British imperial structure. The same is true of the case of Clarence Curling and the inter-racial marriage rage of 1945. These individual stories demonstrate to us, as Ray's entire work does, the complexity of race and relationships within a colonial setting.

Ty M. Reese

University of North Dakota

\section{Harvey Amani Whitfield, North to Bondage: Loyalist Slavery in the Maritimes (Vancouver: UBC Press, 2016). 192 pp. \$95.00 Hardcover.}

In an earlier volume, Blacks Upon the Border: The Black Refugees in British North America, 1815-1900 (2006), Harvey Amani Whitfield offered an admirable study of the black settlers who came to Nova Scotia after the War of 1812. Like their Black Loyalist predecessors after the War of Independence, they often did not receive the lands they were promised for having served the British, or were given inferior allotments that made subsistence difficult. These difficulties notwithstanding, many carved out free lives and created sustainable forms of community. Slavery and indenture, however, were also a common fate of black subjects in Nova Scotia; slavery predated the Loyalists who arrived with their slaves in 1783, free blacks were often forced to indenture themselves, and re-enslavement was a constant risk.

Whitfield's new volume, North to Bondage: Loyalist Slavery in the Maritimes, tells part of that other story. Drawing on data relating to the colonies of Prince Edward Island, Nova Scotia, Cape Breton (Île Royal under the French), and New Brunswick - the latter two were part of Nova Scotia until 1784 Whitfield has produced a thoroughly researched regional study of slavery in the Maritimes. His account is comparative within the Maritime colonies but also with regard to slavery in New England and other parts of the United States, and takes into account the close connections that related the Maritimes through trade, slavery, and migration to the West Indies and the wider British Atlantic.

Citing the more developed scholarship in the United States and the British Caribbean, Whitfield convincingly lays out the case for more detailed work on slavery in the Maritimes. The first monograph on the subject, his book impressively contributes to this task. It draws on a wealth of specific cases drawn from an ap- 